Ankara Üniversitesi Türk Inkılâp Tarihi Enstitïsü Atatürk Yolu Dergisi S 27-28, Mayts-Kasım 2001, s. 299-319

\title{
Ermeni İstekleri Karşısında Millî Teşekküllerin Tutumu (1919-1922)
}

\author{
Dr. Erdal ILTER
}

\section{ÖZET}

Birinci Dünya Savaşı sonunda Itilaf Devletleri ve Osmanlı Imparatorluğu arasında 30 Ekim 1918 tarihinde imzalanan Mondros Mütarekesi, Osmanlı ülkesini parçalayıp işgal edilmeye hazır duruma getirmişti. Ermeniler de müttefiki olduklar İtilaf Devletleri 'nin desteğini alarak Doğu ve Güneydoğu Anadolu'da bağınsız bir Ermenistan kurulması amacıyla milletlerarası platformda çeşitli girişimlerde bulunmuşlardır.

Bu makalede, İtilaf Devletleri ve özellikle Ermenilerin girișimlerinin yanı sıra ulu önder Atatürk'ün işgalci devletlerin amaçlarına ulaşmalarını engelleme ve modern Türkiye'nin kurulmast yolunda, ulusuyla bütünleşerek milli direnişi başlatması ve başarıyla sonuçlanan çalışmaları anlatılmaya çalışılmıştır.

\section{ABSTRACT}

The Armistice of Mondros between the Allied Powers and the Ottoman Empire signed at the end of World War I, on 30 $0^{\text {th }}$ October, 1918 caused the land of Ottoman Empire ready to be shred and occupied. Armenians with the support of the Allied Powers whom they are an ally of, attempted on an international paltform to found an independent armenia in the East and south-East part of Turkey/ Anatolia.

In this article, apart from the Armenians' and the Allied Powers' attempts to break Turkey into pieces, the great leader Atatürk's starting of the War of Independence to prevent the occupying countries from reaching their arms and Ataturk's successful efforts in the establishment of Modern Turkey have also been mentioned.

\footnotetext{
Araștırmacı-Yazar.
} 


\section{GİRIŞ}

Millî Mücadele yıllarında, Ermeni partilerinin Doğu ve Güneydoğu Anadolu'da bir Ermenistan yaratmak amacı ile giriştikleri eylemler yanında, İtilâf Devletleri'nin Osmanlı İmparatorluğu topraklarını aralarında paylaşmak üzere siyasî ve askerî yönden milletler arası platformlardaki çabaları, modern Türkiye'nin doğuşunda mühim etkiler yapmıştır.

İşte biz bu çalışmamızda, modern Türkiye'nin kurucusu Atatürk'ün, Millî Mücadele yıllarında İtilâf Devletleri ile onların müttefiki olan Ermeniler'e nasıl karşı durduğunu ele aldık ve çok geniş inceleme gerektiren bu sahada, elimizdeki kaynaklar çerçevesinde konuya açıklık getirmeye çalıştık.

\section{Mondros Mütarekesi ve Ermeni İstekleri}

\subsection{Mondros Mütarekesi'nde Ermeni Devleti Kurulmast Yolunda Atılan Adımlar ve Ermeni Patriği Zaven Efendi'nin Çalışmaları}

Birinci Dünya Savaşı sonunda İtilâf Devletleri ile Osmanlı İmparatorluğu arasında 30 Ekim 1918 tarihinde imzalanan Mondros Mütarekesi, Osmanlı ülkesinin işgaline imkân hazırlıyordu. Artık ülke yabancılar tarafından parçalanıp işgal edilmeye hazır durumda idi.

Mütareke'nin Ermeniler ve Ermenistan ile ilgili maddeleri şunlard $1^{\prime}$ :

Madde 4 - İtilâf hükûmatına mensup üsera-yı harbiye ile Ermeni üsera ve mevkufini İstanbul'da cemedilecek ve bilâkaydü şart itilâf hükümetlerine teslim olunacaktır.

Madde 24 - Vilâyat-1 sittede iğtişaş zuhurunda mezkûr vilâyetlerin herhangi bir kısmının işgali hakkını itilâf devletleri muhafaza ederler.

Ayrıca, mütarekenin 7. Madde'si ile de imparatorluğun toprak bütünlügüüne müdahalede bulunuluyordu²:

Madde 7 - Müttefikler emniyetlerini tehdit edecek vaziyet zuhurunda herhangi sevkulceyşi noktasını işgal hakkını haiz olacaklardır.

Bu durum, Yıldırım Orduları Grubu Komutanlığı'na atanan Mustafa Kemal Paşa'yı harekete geçirmiştir. O, Adana'dan Sadrazam Ahmet İzzet Paşa'ya çektiği 3 Kasım 1918 ve 8 Kasım 1918 tarihli telgraflarında ${ }^{3}$,

\footnotetext{
${ }^{1}$ Nihat Erim, Devletlerarası Hukuku ve Siyasî Tarih Metinleri: Osmanlı Imparatorluğu Andlaşmaları, Cilt I, Ankara 1953, s. 520, 524.

${ }^{2}$ Nihat Erim, a.g.e., s. 520-521.

${ }^{3}$ Utkan Kocatürk, Doğumundan Ölümüne Kadar Kaynakçalı Atatürk Günlüğü, Ankara 1988, s. 72, 73 .
} 
mütarekenin bazı hükümlerinin Osmanlı Devleti'nin korunmasını sağlayacak anlam ve içerikte olmadığını belirtiyordu.

Mondros Mütarekesi'nin 24. Madde'sinde geçen "Vilâyat-1 Sitte” (altı vilâyet) sözü, Ermenistan kurulması ortamı için önemli bir adım idi. Diğer taraftan, 6 Aralık 1918 tarihinde İstanbul'a gelen Ermeni Patriği Zaven Efendi ${ }^{4}$ de, bağımsız Ermenistan kurulması için bir teşkilât kurmuştu ${ }^{5}$. Zaven Efendi, silâh, mermi ve para yardımlarını toplayarak maddî yönden noksanlarını tamamlamaya çalıșmış, Rum Patrikhanesi'nden geniş ölçüde destek almıştı. Bu dönemde ve sonrasında, Ermeni propagandasının en çok kullandığı ve en etkili görünen sloganı ise "Mazlum Ermenistan" ve "Katliâmlar" teması idi'.

Böylece Ermeniler, yoğun bir propaganda ve siyasî faaliyet içinde bulunuyorlar ve bir Ermenistan kurulması yolundaki isteklerinin müttefiklerince (İngiltere-Fransa) kabul göreceğini düșünüyorlardı. Bu sebeple, Türkiye Ermenileri'nin temsilcisi olduğu sıfatı ile Bogos Nubar Paşa, 30 Kasım 1918 tarihinde İtilâf Devletleri'ne başvurarak, bağımsız bir Ermenistan'ın kurulmasını ve bu bağımsızlığın İtilâf Devletleri ile Cemiyet-i Akvam'ın himayesi altına konulmasını istedi ${ }^{7}$. Diğger taraftan, aynı meselenin gerçekleşmesi hususunda çalışmalarda bulunmak üzere Patrik Zaven Efendi, 12 Şubat 1919 tarihinde İstanbul'dan Paris'e ve oradan da Londra'ya hareket etti. Bogos Nubar Paşa ile de görüşerek onu bazı hususlarda aydınlatan Zaven Efendi, bir taraftan da Lord Cecil, Lord Curzon ve yardımcisı Lord Harding ile görüştü, Fransız Chambon ve Yunan Başbakanı Venizelos ile müzakerelerde bulundu ${ }^{8}$. Ermeniler'in minnettarlı̆̆ını arzetmek üzere İngiltere kıralı V. George'u ziyaret etti ${ }^{9}$. Londra'dan Paris'e dönüşünde ise Fransa Cumhurbaşkanı ve Başbakanı ile görüșen Zaven Efendi, sonuçtan çok emin görünüyordu ${ }^{10}$. Ancak Ermeniler isteklerinde, demografik, etnik, politik, ekonomik ve diğer bakımlardan haklı olup olmadıklarını düşünmüyorlardı.

${ }^{4}$ 1898-1906 yılları arasında Erzurum'da, 1910'da Van'da, 1909-1913 yılları arasında Diyarbakır'da piskopos olarak çalışan Zaven Efendi, Eylül-1913'de İstanbul Ermeni Patriği seçilmiş, ancak zararlı faaliyetleri sebebi ile 1916'da Bağdad'a gönderilmiş, 1918'de Mondros Mütarekesi'ni müteakip İstanbul'a dönmüştür. Daha fazla bilgi için bkz., Christopher J. Walker, Armenia: The Survival of a Nation, London 1980, s. 426-427; Ayrica bkz., Zeki Sarıhan, Kurtuluş Savaşı Günlüğ̈̈, I, Ankara 1993, s. 136-137.

${ }^{5}$ M. Kemal Atatürk, Nutuk, I, 1919-1920, İstanbul 1967, s. 2; Selâhattin Tansel, Mondros'tan Mudanya'ya Kadar, I, Ankara 1973, s. 106.

${ }^{6}$ Yahya Akyüz, Türk Kurtuluş Savaşı ve Fransız Kamuoyu (1919-1922), Ankara 1975, s. 86.

${ }^{7}$ Bogos Nubar Paşa'nın müracaat metni için bkz., Esat Uras, Tarihte Ermeniler ve Ermeni Meselesi, Ankara 1950, s. 672-673.

${ }^{\mathrm{x}}$ Esat Uras, a.g.e., s. 696.

${ }^{9}$ Esat Uras, a.g.e., s. 696.

${ }^{10}$ Esat Uras, a.g.e., s. 699. 


\subsection{Paris Barış Konferansı'nda Ermeni İstekleri}

Paris Barış Konferansı'nın toplanması, dört yıl sürmüş olan Birinci Dünya Savaşı'na sonuç getirmek, savaşan devletleri barış şartları çerçevesinde toplamak amacı ile kararlaştırılmıștı. 1919 yılı Ocak ayında toplanan bu konferansta, Birinci Dünya Savaşı'nın muhasebesi yapılırken, Osmanlı İmparatorluğu'nun da kaderi çizilecekti. Aslında Mondros Mütarekesi ile imparatorluk son bulmuş sayılırdı. Ancak Paris Konferansı'nda ele alınacak olan husus, Anadolu'nun paylaşılması idi. İște şimdi Ermeniler'in karşısına, bizzat temsilci göndermek sureti ile seslerini duyurabilecekleri bir barış konferansı çıkmıştı. Onlar, bundan faydalanarak amaçlarını gerçekleştirebilecekleri inancında idiler.

Ermeniler bu amaçla, Mondros Mütarekesi'nden sonra diplomatik faaliyetlerde bulunmak ve propagandaya girişmek üzere Paris'e üç ayrı hey'et göndermişlerdi. Bunlar, Bogos Nubar Paşa (1851-1930)'nın başkanlığındaki "Avrupa Millî Ermeni Delegasyonu", Ermenistan Cumhuriyeti Cumhurbaşkanı Avadis Aharonyan (1866-1948) başkanlığındaki "Ermeni Cumhuriyeti Delegasyonu" ve Kilikya (Sis) Ermeni Katogigosu Paul Terziyan'ın başkanlığında kurulmuş bir din adamları (ruhanî) Delegasyonu idi" ${ }^{11}$. Ancak, bu hey'etlerden hiç birinin Paris Barış Konferansı'nda sürekli temsilciliği kabul edilmedi. Fakat Barış Konferansı, 26 Şubat 1919 tarihinde, Ermeni temsilcilerinin Ermeni toplumu adına isteklerinin açıklanmasına izin verdi. Bogos Nubar Paşa ve Avedis Aharonyan, 26 Şubat 1919 tarihinde Konferans'ın "Onlar Șûrası"na verdikleri muhtıra ile Ermeni isteklerini açıkladılar ${ }^{12}$. Bu isteklere göre, kurulacak Büyük Ermenistan'a şu vilâyetler dahil edilmeli idi ${ }^{13}$.

a. Van, Bitlis, Diyarbakır, Harput, Sivas, Erzurum ve Trabzon vilâyetlerini içine alan, Türkiye'nin yedi Doğu vilâyeti,

b. Güney ve Güneydoğu Anadolu'da Maraş, Kozan, Cebel-i Bereket (Dörtyol), Mersin ve İskenderun limanı ile birlikte Adana.

Böylece mutasavver bağımsız Ermeni devleti, Toroslar'dan ve Sivas yaylasından itibaren Anadolu'nun bütün doğu kısmını işgal etmiș olacak, Karadeniz ve Akdeniz'de de kıyısı bulunacaktı. Ermeniler'in bu istekleri Kilikya (Cukurova ve Maraș havalisi)' $y_{1}$ da kapsayınca Fransızlar desteklerini geri çektiler, ama İngilizler Ruslar'ın Doğu Anadolu'dan Akdeniz yönünde yayılmasını istemediğinden bu bölgede dost bir tampon

" H. Pasdermadjian, Histoire de L'Arménie, Paris 1949-1971, s. 424; Christopher J. Walker, a.g.e., s. 265; Yahya Akyüz, a.g.e., s. 81; Rouben Paul Adalian. Historical Dictionary of Armenia, Lanham, Maryland and Oxford 2002, s. 8, 124.

${ }^{12}$ Gotthard Jaeschke, Türk Kurtuluş Savașt Kronolojisi, I, Ankara 1970, s. 19; Yahya Akyüz, a.g.e., s. 82.

${ }^{13}$ Salâhi R. Sonyel, Türk Kurtuluş Savașı ve Dış Politika, I, Ankara 1973, s. 21; Yahya Akyüz, a.g.e., s. 82. 
devletin bulunmasının yararlı olacağı inancında idi ${ }^{14}$. Ermeni istekleri gerçekleştiği takdirde, Wilson prensiplerinin dayanmakta olduğu "self determination" (milletlerin kendi kendilerini yönetme ilkesi) Türkiye açısından geçersiz kalacaktı. Ermeniler ise, Wilson'un bu ilkesini terkedip kendilerini desteklemesi için baskı yapıyorlardı.

Barış Konferansı'nda Osmanlılar ile ilgili meselelerin tartışılmasına, Lloyd George'un; Wilson'a Amerika'nın mandayı kabul etmesi önerisinin 21 Mayıs 1919 tarihinde yapılmasından sonra başland ${ }^{15}$. Ancak, Amerikalı uzmanların 22 Haziran 1919 tarihinde konferansa sundukları raporda: “Ermenistan'ın işgal edilmemiş olan kısmını işgal etmek için Ermeniler'e verilmek üzere 50 bin silâha, Ermeniler'in (buralara) dönmesini sağlamak için de 60 bin kişilik bir yabancı kuvvete ve kurulacak bir Ermeni hükümetine yardım ve asayişi korumak üzere de, yıllarca en az 30 bin kişilik bir kuvvete lüzum olduğu"16 belirtiliyordu. İște bu kuvvetlerin kimin tarafından verileceği konferansta bahis konusu olduğu zaman meselenin güçlüğü hemen meydana çıkmıştı. Özellikle, İngiltere ve Fransa arasındaki bölgeye hakimiyet mücadelesi, konunun bir müddet daha sürüncemede kalmasına sebep olacaktı. Büyük devletlerin bölgeye kuvvet göndermelerindeki mütereddid durumlarına rağmen, Türkiye'deki Ermeniler de, taşkınlıklara başlamışlardı.

\section{3. İsgaller ve Millî Mücadele'nin Başlaması}

Paris Barış Konferansı kararı ile 15 Mayıs 1919 tarihinde İzmir, İngiliz, Fransız ve Amerikan koruyuculuğu altında Yunanlılar tarafından işgal edilirken, Mustafa Kemal Paşa'da İstanbul'dan Bandırma vapuru ile Karadeniz'e açılıyor, IX. Ordu Müfettişi olarak 19 Mayıs 1919 tarihinde Samsun'da Anadolu topraklarına ayak basıyordu. İzmir'in bu haksız ve sebepsiz işgali Türk Milleti tarafından tiksinti ile karşılandı ve istilâ ordularına karşı silâhlı mukavemete geçti. Böylece, Mustafa Kemal'in önderliğinde Millî Mücadele başlamış oluyordu.

15 Eylül 1919 tarihindeki "Suriye ve Kilikya'da işgal kuvvetlerinin tebdili hakkındaki İngiliz-Fransız mukavelesi"ne göre ${ }^{17}$ de, daha önce İngilizler tarafından işgal edilen Antep, Maraş ve Urfa, Ekim-Kasım 1919'da Fransızlar tarafından devralınacaktır ${ }^{18}$.

\footnotetext{
${ }^{14}$ Stanford J. Shaw and Ezel Kural Shaw, History of the Ottoman Empire and Modern Turkey, II, Reprinted 1978, s. 330-331.

${ }^{15}$ Mine Erol, Türkiye'de Amerikan Mandası Meselesi (1919-1920), Giresun 1972, s. 14.

${ }^{16}$ Tevfik Biyıklığlu, Atatürk Anadolu'da (1919-1921), I. Ankara 1959, s. 4.

${ }^{17}$ Gotthard Jaeschke, a.g.e., I, s. 64.

${ }^{18}$ Utkan Kocatürk. Atatürk ve Türkiye Cumhuriyeti Tarihi Kronolojisi, 1918-1938. Ankara 1983, s. 112-113.
} 


\section{2. İşgale Karşı Millî Hakların Müdafaası: Alınan Askerî ve Siyaŝ̂ Tedbirler}

Osmanlı hükümetlerinin yurdun işgaline kayıtsız kalmaları ve işgal kuvvetlerinin varlığı ile şımaran Ermeniler'in davranışı Türk halkında öfke ve kızgınlık yaratmıș, millî şuuru kamçılamıștı. Diğer taraftan, Trakya'nın ve Batı Anadolu'nun Yunanistan'a, Doğu Anadolu'nun Ermeniler'e verileceği, Çukurova'nın Türkiye'den alınacağı ve Karadeniz kıyılarında Samsun-Trabzon yöresinde Pontus Rum Devleti kurulacağ endişeleri de yurtta bir Müdafaa-i Hukuk hareketinin doğmasına sebep olmuştu. Trakya Paşaeli Müdafaa-i Hukuk Cemiyeti, İzmir Müdafaa-i Hukuk-u Osmaniye Cemiyeti, İzmir Redd-i İlhak Cemiyeti, Kilikyalılar Cemiyeti, Vilâyât-1 Şarkiye Müdafaa-i Hukuk Cemiyeti, Trabzon Muhafaza-i Hukuk-u Milliye Cemiyeti gibi cemiyetler, vatanın kurtarılması yolunda faaliyete başlamışlardı ${ }^{19}$. Böylece İtilâf Devletleri, Türkiye'nin taksimine yol bulmak amacı ile Yunanlılar'a işgal ettirdikleri Batı Anadolu'da yaptırdıkları baskı, öldürme ve yok etme hareketlerini, bu defa da Ermeniler vasıtası ile Güney'de Adana, Mersin, Tarsus, Maraş, Urfa, Antep'de uyguluyorlardı. Bu sebeple Türk Milleti, kurtuluş çareleri arıyor ve silâhlanıyordu.

\subsection{Kars, Ardahan ve Oltu Kongreleri}

İşgaller karşısında Türk milliyetçilerini kaygılandıran en önemli meselelerden biri, Ermeniler'in Doğu Anadolu illerine göz dikmeleri idi. Mondros Mütarekesi'nden sonra kurulan Millî Cemiyetler'in müșterek amacı, "Millî azınlıkların tecavüzlerine karşı millî hakların müdafaası" idi $^{20}$.

Mondros Mütarekesi'nin 11. Madde'sinde geçen aşağıdaki ifadeler Türk makamlarını tedirgin etmiştir ${ }^{21}$ :

"İran'ın şimalî garbî kısmındaki kuva-yı Osmaniye'nin derhal harpten evvelki hudut gerisine celbi hususunda evvelce ita edilen emir icra edilecektir. Mavera-y1 Kafkas'ın evvelce Kuva-yı Osmaniye tarafından kısmen tahliyesi emredildiğinden kısm-1 mütebakisi müttefikler tarafından vaziyet-i mahalliye tetkik edilerek talep olunursa tahliye edilecektir."

Bu sebepten ve Kafkasya'dan Türk ordusunun resmen çekilişi üzerine, yerli Müslümanlar vatanlarını savunmak için milis teşkilâtı esasına dayanan millî ve siyasî teşkilâtlarını kurma faaliyetine girişmişlerdi.

\footnotetext{
${ }^{19}$ Tevfik Bıyıklığlu, Trakya'da Millî Mücadele, I. Cilt, 2. Baskı, Ankara 1987, s. 123 144; Tarık Zafer Tunaya, Türkiye'de Siyasal Partiler, II. Cilt, 2. Baskı, İstanbul 1986, s. 156; Sabahattin Selek, Anadolu Ihtilâli, 4. Baskı, İstanbul 1968, s. 96-97.

${ }^{20}$ Tevfik Bıyıklığlu, Atatürk Anadolu'da (1919-1921), I, s. 8.

${ }^{21}$ Nihat Erim, a.g.e., s. 521.
} 
Doğu Anadolu'da üç liva 22 "Kars, Ardahan, Oltu" (Elviye-i Selâse)'yu içine alan hareket ilk kongresini 14 Kasım 1918'de Kars'da toplamış, bunu 30 Kasım 1918'de toplanan II. Kars, 3-5 Ocak/7-9 Ocak 1919'da toplanan Ardahan, 17/18 Ocak 1919'da toplanan Kars ve 21 Şubat 1920'de toplanan Oltu kongreleri izlemiştir ${ }^{23}$. Bu kongrelerin başlıca amacı, Wilson prensiplerine dayanarak devletçe kabul edilen Mondros Mütarekesi şartlarını uygulatmamak, ordumuzun çekileceği Batum'dan Nahçıan'a kadar uzanan Güneybatı Kafkas topraklarını korumak ve bu toprakların meşrû sahibi olduklarını ifade ile Türkiye'den ayrılmamaktı ${ }^{24}$. Zafere kadar çarpışılacak, her il ve ilçede, "Millî Şûra" şubeleri açılacaktı. Diğer taraftan, yayın ve delegeler aracılı̆̆ ile de millî haklar tanitılacaktı.

Özellikle, 17/18 Ocak 1919 tarihinde Kars'da 131 delegenin iştiraki ile toplanan Büyük Kars Kongresi ve aldığı kararlar, nev'î şahsına münhasır olarak Millî Mücadele tarihimizdeki mümtaz yerini almıştır. Bu kongrede alınan kararla "Cenubugarbî Kafkas Hükümeti Muvakkata-i Millîyesi" adı ile bir yönetim kurulmuş ve yönetim 25 Mart 1919 tarihinden itibaren de "Cenubugarbî Kafkas Hükümeti Cumhuriyesi” adını kullanmaya başlayacaktır ${ }^{25}$.

13 Şubat 1919 tarihinde Kars’a giren İngilizler, Mutasarrıf Hilmi (Uran) Bey'in direktifi üzerine kurulan Millî İslâm Şûrâsı (Hükümeti)'nı tanımışlardı. Ancak, İngiliz komutanlığının bu bölgeye Ermeni göçmenlerin getirilmesini ve vali olarak da bir Ermeni (Garganof)'nin atanmasına muvafakat edilmesini istemesi ve hükümetin (Şûra'nın) bu teklifi reddetmesi üzerine ilişkiler kopacaktır ${ }^{26}$. Bunun üzerine, bölgedeki İngiliz generali Thompson, 12 Nisan 1919 tarihinde parlamento binasını basıp, hükümet üyelerini tutuklatarak Malta adasına sürdü. Ertesi günü, 13 Nisan 1919'da İngilizler'in Kars'1 işgal ettiklerini ilân etmeleri ile birlikte, Ermeni Osebyan ile Garganof idareyi ele aldılar ${ }^{27}$. Diğer taraftan, Anadolu'da "İmparatorluğu

${ }^{22}$ Liva, Osmanlı idari teşkilâtında kaza ile vilâyet arasında bulunan bir idare makamdır. Buna sancak da denilmekte idi. Kazalar livaya, livalar vilâyetlere bağlı bulunurlardı. Bu teşkilât, Cumhuriyet'in ilânını müteakip ilga olunmuş ve kazalar (ilçe) doğrudan doğruya vilâyetlere (il) bağlanmıştır.

${ }^{23}$ Daha geniş bilgi için bkz., M. Fahrettin Kırzıoğlu, Kars Tarihi, I, İstanbul 1953, s. 556557; Aynı yazar, Millî Mücadelede Kars, I. Kitap, İstanbul 1960, s. 8-10; Erdal İlter, “Ardahan'ın Düşman İşgalinden Kurtuluşunun 52. Yıl Dönümü,” Türk Kültürü, Sayı: 123 (Ocak 1973), s. 129-137.

${ }^{24}$ M. Fahrettin Kırzıoğlu, Kars Ili ve Çevresinde Ermeni Mezâlimi (1918-1920), Ankara 1970, s. 75-76.

${ }^{25}$ Utkan Kocatürk, a.g.e., s. 18.

${ }^{26}$ Gotthard Jaeschke, Kurtuluş Savaşı Ile Il gili Ingiliz Belgeleri, Ankara 1971, s. 44.

${ }^{27}$ M. Fahrettin Kırzıoğlu, Millî Mücadelede Kars, I. Kitap, s. 11-12; Gotthard Jaeschke, a.g.e., gösterilen yer; Tevfik Bıyıklığlu, a.g.e, I, s. 10; Osebyan ve Garganof'un Kars'da idareyi ancak 30 Nisan'da ellerine alabildikleri hkn. bkz., M. Fahrettin Kırzıoğlu, "Cihângîroğlu İbrâhim Aydın (1874-1948)'daki Millî- Mücadele'de Kars ve Atatürk ile İlgili Belgeler," Belleten, Sayı: 189-190 (Ocak-Nisan 1984), s. 116. 
Koruyalım" kampanyasının Türkler lehine değişeceği görülüyordu. 18 Nisan 1919 tarihinde Erzurumlular, 25 Nisan'da da Diyarbakırlılar Bâb-1 Âli'ye çektikleri telgraflarda Ermeni tehlikesine dikkat çekerek, Doğu ve Güneydoğu Anadolu'nun Osmanlı İmparatorluğu'nun ayrılmaz parçaları olduğunu ifade ediyorlard ${ }^{28}$.

Mondros Mütarekesi, İtilâf Devletleri'ne müdahale ve işgal yetkisini tanıyordu. Ermeniler de tahrik edilerek, bu bahane sağlanabilirdi. Nitekim, yöre Ermenileri'nin "Bizi İslâmlar aleyhine teşvik eden ve katliâma sebep olan İngilizler'dir. İngilizler bize (Ermeniler'e), bizim dostluğumuza bakmayın, siz İslâmları öldürün, silâh ve cephane bizden." dedikleri ve Ermeni saldırılarında Ermeniler'e İngiliz üniforması dağıtıldığ bilinmektedir ${ }^{29}$.

\subsection{Trabzon, Erzurum ve Sivas Kongreleri}

Birinci Dünya Savaşı sonlarında Ruslar'ın terkettikleri Trabzon ve çevresinde Ermeni ve özellikle Rum çeteleri faaliyetlerde bulunuyor, tedhiş hareketi gittikçe artıyordu. Bu Ermeni ve Rum tehlikesine karşı, bölgenin Türklügüüü savunmak için mahallî teşkilâtlanmaya gitmek amacı ile 23 Şubat 1919 tarihinde Trabzon Muhafaza-i Hukuk-u Milliye Cemiyeti'nin Birinci Kongre'si yapılıyordu. Cemiyet, yaptığ 1 bu kongresinde aldığ 1 kararlarında, bilimsel yayınlar, propagandalar ve bildiriler yayınlayıp Nota'lar vermek şeklinde bir çalışma esasını benimsemişti. Önemi, çeşitli vilâyetlerde toplanan benzer kongrelerin ilki olmasından kaynaklanmakta idi $^{30}$. Mart 1919 başlarından itibaren şubelerini vilâyetin her köşesine yayan cemiyet, kısa zamanda Rize, Giresun, Ordu ve Of'da şubeler kurdu. Böylece, tehlikeye karşı halkın uyanıklığı ve beraberliği sağlanmış oluyordu.

Trabzon Muhafaza-i Hukuk-u Milliye Cemiyeti, Paris Barış Konferansı'na götürülmesi amacı ile eski Sadrazam Tevfik Paşa'ya verdiği bir muhtırada ${ }^{31}$ : "Trabzon'un Ermenistan için bir mahreç ittihaz edileceği ve bunun Trabzon'u parçalamaya, oradaki Türk ve Müslümanlar'ın hukuk-u milliye ve tarihiyesini çiğnetmeye sebep teşkil edecek bir silindir mesabesinde" olduğu belirtiliyordu. Diğer taraftan, Pontus hülyasına kapılmış olan Yunan Başbakanı Venizelos, denize çıkış temin etmek için Trabzon vilâyetini Ermeniler'e bırakacağını vaad ediyordu ${ }^{32}$. Yüksek Komiser Amiral Richard Webb de, Trabzon'da nerede ise hiç Ermeni

\footnotetext{
${ }^{28} \mathrm{M}$. Kemal Öke, Ingiltere'nin Güneydoğu Anadolu Siyaseti ve Binbaşı E. W. C. Noel'in Faaliyetleri, Ankara 1988, s. 46.

${ }^{29}$ Kâzım Karabekir, İstiklâl Harbimiz, İstanbul 1969, s. 295.

30 İzzet Öztoprak, "Trabzon Muhafaza-i Hukuk-u Milliye Cemiyeti," Birinci Tarih Boyunca Karadeniz Kongresi Bildirileri, Samsun 1988, s. 335-350.

${ }^{31}$ İzzet Öztoprak, a.g.m., s. 345.

${ }^{32}$ Gotthard Jaeschke, a.g.e., s. 56.
} 
bulunmadığını, ancak buna rağmen vilâyetin Ermeni Devleti'ne bırakılacağını belirtiyordu ${ }^{33}$.

Trabzon Muhafaza-i Hukuk-u Milliye Cemiyeti, Eylül 1919'da toplanan Sivas Kongresi'nden sonra Anadolu ve Rumeli Müdafaa-i Hukuk Cemiyeti'nin bir şubesi haline gelecektir.

Mustafa Kemal Paşa, Samsun'a çıktığı zaman Anadolu iki büyük kongrenin eşiğinde bulunuyordu. Batı Anadolu'yu Yunan işgalinden kurtarmak isteyen mahallî teşkilâtlar Balıkesir'de, Doğu'da bir Ermenistan kurulmasını önlemeye çalışanlar ise Erzurum'da toplanacaklardı. Samsun'dan Amasya'ya geçen Mustafa Kemal Pașa, orada millî bir hareket taraftarı olan Ali Fuat Paşa, Rauf Bey ve Refet Paşa ile bir araya gelerek sekiz hususta mutabakata vardı. Toplantıya katılamayan ve fakat desteklerinin sağlanması gerekli olan XV. Kolordu Kumandanı Kâzım Karabekir Paşa ve Konya Yıldırım Kıt'aları (III. Kolordu) Müfettişi Mersinli Cemal Paşa'ya telgrafla danışılarak onların da alınan kararlara katılmaları mümkün kılındı. Ali Fuat Paşa'nın "Mukaddes İttifak" dediği bu Amasya Tâmimi (21-22 Haziran 1919)'nin esasları şunlard 13.

a. Yurdun bütünlüğü, milletin istiklâli tehlikededir,

b. İstanbul'daki hükümet, üzerine aldığı sorumluluğun gereklerini yerine getirememektedir.

c. Milletin istiklâlini yine milletin âzim ve kararı kurtaracaktır,

d. Milletin durumunu ve davranıșını gözönünde tutmak ve haklarını dile getirip bütün dünyaya duyurmak için her türlü etkiden ve denetimden kurtulmuş millî bir kurulun varlığı gereklidir,

e. Anadolu'nun her yönden en güvenli yeri olan Sivas'da millî bir kongrenin tez elden toplanması kararlaştırılmıştır,

f. Bunun için bütün illerin her sancağından, halkın güvenini kazanmış üç delegenin mümkün olan sür'atle hemen yola çıkarılması gerekmektedir,

g. Herhangi bir kötü durumla karşılaşılabileceği düşünülerek bu iş, millî bir sır gibi tutulmalı ve delegeler gereken yerlere kimliklerini gizleyerek gelmelidirler,

h. Doğu illeri adına 10 Temmuz'da Erzurum'da bir kongre toplanacaktır. O güne kadar diğer il delegeleri de Sivas'a ulaşabilirlerse, Erzurum Kongresi'nin delegeleri de Sivas'da yapılacak genel kongreye katılmak üzere yola çıkarlar.

\footnotetext{
${ }^{33}$ M. Kemal Öke, a.g.e., s. 73 ,

${ }^{34}$ M. Tayyib Gökbilgin. Millî Mücadele Başlarken: Mondros Mütarekesinden Sivas Kongresine. I. Ankara 1959, s. 146-148.
} 
Amasya Tâmimi'nde yer alan en önemli hüküm, șüphesiz 'Milletin istiklâlini yine milletin âzim ve kararı kurtaracaktır." parolası idi.

Amasya'dan sonra 3 Temmuz 1919 tarihinde Erzurum'a geçen Mustafa Kemal Paşa, Doğu'daki Müdafaa-i Hukuk Cemiyetleri'nin birleşmesini amaç edinen Erzurum Kongresi'nin hazırlıklarına katıldı. Diğer taraftan, İngiliz Yüksek Komiseri Amiral Carlthorpe ile İşgal Kuvvetleri Başkomutanı General Milne'nin, Mustafa Kemal'in geri çağırılması ve Anadolu'daki millî hareketin bastırılması için Osmanlı Hükümeti'ni sıkıştırmaları da devam ediyordu. İngilizler'in baskısı ile ordudan çıkarılmak üzere olduğunu Genelkurmay Başkanı Cevat Paşa'dan öğrenen Mustafa Kemal Paşa, 9 Temmuz 1919 tarihinde istifasını veriyor ve millete hitap eden genelgesinde ${ }^{35}$, "vatanı ve milleti parçalanmak tehlikesinden kurtarmak, Yunan ve Ermeni isteklerine kurban etmemek için açılan millî savaş uğrunda milletle beraber serbest surette çalışmaya resmî ve askerî sıfatının engel olmaya başladığını, bu mukaddes gaye için milletle beraber sonuna kadar çalışmaya mukaddesatı adına söz vermiş olduğunu ve âşıkı bulunduğu askerlik mesleğinden çekildiğini”" bildiriyordu.

Bu arada, Erzurum'un Ermeniler'e verileceği haberi Erzurumlular'ı galeyana getirirken, İzmir'in Yunanlılar tarafından işgali, bütün yurtta olduğu gibi Erzurum'da da etkisini göstermişti. İzmir'in başına gelenlerin Erzurum'un başına da gelebileceği belirtilerek önlem alınması isteniyordu ${ }^{36}$. Böylece, 17 Haziran 1919 tarihinde Raif Efendi'nin başkanlığında Vilâyet Kongresi toplanmış, bölgeden hiç göç etmemek ve muhtemel bir Ermeni saldırısına karşı şiddetle karşı durmak ilke olarak kabul edilmişti ${ }^{37}$. Ayrıca kongre, Ermeni propagandasına karşı yayınladığı on sekiz sayfalık bir broşürde de, Türk-Kürt kardeşliğini, kültür ve din birliği ile gelenek ortaklığını tarih ve ilim açısından ele alıp Ermeniler'in bölücü propaganda ve tahriklerini çürütüyordu ${ }^{38}$.

23 Temmuz 1919 tarihinde toplanan Erzurum Kongresi'nde oybirliği ile Başkan seçilen Mustafa Kemal Paşa, konuşmasında ülkenin içinde bulunduğu durumu, İtilâf Devletleri'nin, Mondros Mütarekesi'nin hükümlerine ve Wilson prensiplerine aykırı olarak Türk Milleti'nin her çeşit haklarını çiğnediklerini ve İstanbul Hükümeti’nin aczini belirtmişti. Mustafa

\footnotetext{
${ }^{35}$ Utkan Kocatürk, Doğumundan Ölümüne Kadar Kaynakçalt Atatürk Günlüğü, s. 94.

${ }^{36}$ Bekir Sıtkı Baykal, "İzmir'in Yunanlılar Tarafından İsgali ve Bu Olayın Doğu Anadolu'daki Tepkileri," Belleten, Sayı: 132, Ankara 1969, s. 517-535; Yücel Özkaya, "Izmir'in İşgalinin Anadolu'daki Tepkileri," AÜTiTED, Sayı: 1 (Mayıs 1988), s. 65-74.

${ }^{37}$ Cevat Dursunoğlu, Millî Mücadele'de Erzurum, Ankara 1946, s. 66-67.

${ }^{38}$ Daha geniş bilgi için bkz.. Erzurum Kongresi Ile Ilgili Belgeler, yay.haz.. Bekir Sıtkı Baykal, Ankara 1969, s. 40-52.
} 
Kemal Paşa, burada ayrıca Ermeniler'in durumuna da temas ederek şunları ifade etmiştir ${ }^{39}$ :

“...Tebaa-i Osmaniye'den olan Rum ve Ermeni anasırı gördükleri teşvik ve müzaheretin netayiciyle de namus-u milletimizi cerihadar edecek taşkınlıklardan başlayarak, nihayet hazin ve kanlı safhalara girinceye kadar küstahane tecavüzata koyuldular. Fakat, derin bir telehhüf ile itiraf etmeliyiz ki, bu cüretler, sekiz aydan beri, biribirini takiben mevki-i iktidara geçen, murakabe-i milliyeden azade hükümat-1 merkeziyenin, birinin diğerinden daha fena olarak gösterdiği zaif ve aciz âsarından ve payitahtta ve bazı matbuatta görülen pek mezmum ihtirasattan ve vicdan-1 millinin inkâr, kuvay-1 milliyenin ihmal olunmasından nași vüsat bulmuștur.

Inkısam-1 vatan mevzuubahis ve karar olarak vilâyat-1 șarkiyemizde "Ermenistan", Adana ve Kozan havalisinde "Kilikya" namlarına Ermenistan, Garbî Anadolu'nun İzmir ve Aydın havalisinde Yunanistan, Trakya'da payitahtımızın kapısına kadar kezalik Yunanistan; Karadeniz sahillerimizde "Pontus" kırallığı...tasvip bulmuş ve görülüyor ki tatbikat devresi de başlamıştır.

Ermenistan'a gelince: Bir fikr-i istilâ perverde eden Ermeniler, Nahcivan'dan Oltu'ya kadar bütün ahali-i İslâmiyeyi tazyik ve bazı mahallerde katliâm ve yağmagerlikte bulunuyorlar. Hudutlarımıza kadar İslâmları mahva mahkûm ve hicrete mecbur ederek vilâyat-1 şarkiyemiz hakkındaki emellerine doğru emniyetle takarrüb etmek ve bir taraftan da 400 bin olduğunu iddia eyledikleri Osmanlı Ermenisi'ni bir istinatgâh olmak üzere memleketimize sürmek istiyorlar.

Surada acıklı bir hakikat olmak üzere arz edeyim ki, memleketimizde külliyetli ecnebi parası ve birçok propagandalar cereyan ediyor. Bundaki gaye pek aşikârdır ki, hareket-i milliyeyi akim bırakmak, âmal-i milliyeyi felce uğratmak, Yunan, Ermeni ve bazı aksamı mühimme-i vatan işgal gayelerini teshil etmektir...Fakat mukaddesatının gayeyi necatiyle çırpınan bütün millet işbu tarikı azim ve mücahedesinde her türlü mevanii, muhakkak ve mutlaka kırıp süpürecektir."

Doğu Anadolu'nun meselelerini halletmek için toplanmış olan Erzurum Kongresi, aldığı kararlar itibariyle Millî Mücadele'nin prensiplerini de ortaya koyan ilk kongre olmuştur. Çünkü aldığı kararlar ile yalnız Doğu

39 Atatürk'ün Söylev ve Demeçleri, 1919-1938, I, 3. Baskı, Toplayan: Nimet Arsan, Ankara 1981, s. 3-7. 
vilâyetleri değil, bütün Türk milleti temsil ediliyordu. Alınan prensip ve kararlar kısaca şunlardı ${ }^{40}$ :

a. Millî hudutlar içinde vatan bir bütündür. Onun çeşitli kısımları birbirinden ayrilmaz,

b. Her türlü yabancı işgal ve müdahalesine karşı ve Osmanlı Devleti'nin dağılması halinde millet birlikte müdafaa ve mukavemet edecektir,

c. Vatanın ve istiklâlin muhafaza ve teminine İstanbul'daki hükümet muktedir olamadığı takdirde maksadın temini için geçici bir hükümet teșekkül edecektir. Bu hükümet millî kongrece seçilecektir. Kongre toplanmış değil ise bu seçimi heyet-i temsiliye yapacaktır,

d. Kuvay-ı milliyeyi âmil ve millî iradeyi hâkim kılmak esastır,

e. Hıristiyan unsurlara (azınlıklara) siyasî hâkimiyetimizi ve içtimaî muvazenemizi bozucu imtiyazlar verilemez,

f. Manda ve himaye kabul olunmaz,

g. Millî Meclis'in derhal toplanması ve hükümet icraatının meclisin denetimine konulması için çalışılacaktır.

Böylece Erzurum Kongresi, Anadolu'da millî bir devletin yürütme gücü olan millî bir hükümet kurmak yolundaki azmini ifade etmiş oluyordu. İngiliz Yüksek Komiseri Amiral Carlthorpe da, 29 Temmuz 1919 tarihinde Dışişleri Bakanlığı'na General Milne'nin Ermenilik konusunda aynı paraleldeki bir raporunu gönderiyordu ${ }^{41}$. Milne raporunda, savaşın Nahcivan yakınında ve Oltu'nun güneyinde vukubulduğunu, Büyük Ermenistan sözünün millî hareket ateşini alevlendirdiğini ifade ediyordu. Ermeni Patriği Zaven Efendi ise, Rum Patriği ile birlikte 3 Temmuz 1919 tarihinde, İngiliz Yüksek Komiserliği’ne verdiği dilekçedee ${ }^{42}$, "Türkiye'de...Millî savunma bahanesi altında Hıristiyanlar'a saldırmaları için çeteler ile milisler teşkilâtlandırılmıştır... Asayişsizlikten, esas itibariyle, Türk Hükümeti mesuldur. Doğu Hıristiyanları'nın koruyucusu ve mazlum milletlerin kurtarıcısı olan Müttefikler'in münasip görecekleri tedbirleri almaları için temennilerimizi ortaya koymamız hususuna müsaadelerini rica ediyoruz." diyerek, İtilâf Devletleri'ni işgale teşvik ediyordu..

Erzurum Kongresi'nin toplandığı sıralarda Türkiye'de Amerikan mandası meselesi yeni ortaya çıkmıştı. Türkler'in selâmetini Amerikan mandasında gören pekçok Türk aydını vardı. Meselâ, Amerikan mandası fikrinin ilk

4n Enver Ziya Karal, Türkive Cumhuriyeti Tarihi, 1918-1965, İstanbul 1971, s. 40-41; Geniş bilgi için bkz., Erzurum Kongresi Ile Ilgili Belgeler, yay.haz., Bekir Sıtkı Baykal, s. 2325.

${ }^{41}$ Gotthard Jaeschke, a.g.e., s. 44-45.

${ }^{42}$ Gotthard Jaeschke, a.g.e., s. 51. 
öncüsü ve Wilson Prensipleri Cemiyeti'nin başkurucusu Hâlide Edip (Adıvar) Hanım, manda konusunu incelemek amacı ile Paris'den gönderilen King-Crane Komisyonu ile yakın temasta idi. Bu komisyon, Wilson'a verdiği Yakındoğu Raporu'nda Türkiye ile ilgili olarak Ermenilik konusunda aşağıdaki hususları gündeme getirmişti ${ }^{43}$ :

a. Kilikya hâriç, bir Ermeni mandası kurulması,

b. Bütün Anadolu'yu, Ermenistan, İstanbul Devleti ve Türk Devleti'ni kapsayacak tek bir genel manda kurularak bunun Amerika Birleşik Devletleri'ne verilmesi.

Halbuki, Mustafa Kemal Paşa, tek bir karar almıştı ve onu şöyle açıklıyordu ${ }^{44}$ :

"Efendiler, bu vaziyet karşısında bir tek karar vardı. O da hâkimiyet-i milliyeye müstenit, bilâkaydüşart müstakil yeni bir Türk Devleti tesis etmek."

Paris Barış Konferansı tarafından benimsenen Doğu vilâyetlerinde manda kurulması kararına karşı da, Erzurum Kongresi aldı ̆̆ı kararda, "Manda ve himaye kabul olunmaz." maddesini koymuştu.

Erzurum Kongresi ile Doğu vilâyetlerinin vatanın bölünmez bir parçası olduğu ve bu vilâyetlerin anavatandan ayrılmamaları için karar verilirken, daha kapsamlı ikinci bir kongrenin, Batı vilâyetlerinden gelecek temsilciler ile en güvenli bölge olarak görülen Sivas'da toplanması hazırlıkları da başlamıştı. Aslında, Sivas'da bir kongre toplanması kararı Amasya Genelgesi ile verilmişti. Erzurum'daki çalışmalarını tamamlayan Mustafa Kemal Paşa, 2 Eylül 1919 tarihinde halkın gösterileri arasında Sivas’a geldi.

4-12 Eylül 1919 tarihleri arasında toplanan Sivas Kongresi, Doğu ve Batı Anadolu'daki Müdafaa-i Hukuk Cemiyetleri'nin bir merkeze bağlanmasını mümkün kılmıştır. Seçilen Heyet-i Temsiliye'nin başına Mustafa Kemal Paşa getirilmiş ve bütün Anadolu'nun milliyetçi örgütü "Anadolu ve Rumeli Müdafaa-i Hukuk Cemiyeti” adını almıştır.

Mustafa Kemal Paşa, Sivas Kongresi'ni açış konuşmasında, ülkenin içinde bulunduğu duruma temas ederek Ermeniler'in faaliyetleri hakkında şöyle diyordu ${ }^{45}$ :

"Muhterem Efendiler...Şarkta Ermeniler Kızılırmak'a kadar tevessü hazırlıklarına ve şimdiden hudutlarımıza kadar dayanan katliâm siyasetine başladı. Karadeniz sahillerimizde Pontus kırallı̆̆ı hayalinin tahakkukuna bile çalışıldı...Şarkta harb-i zailin her türlü meşakkat ve elemlerini görmüş ve

\footnotetext{
${ }^{43}$ Fethî Tevetoğlu, Millî Mücâdele Yıllarmdaki Kuruluşlar. Ankara 1988, s. 184.

${ }^{44}$ M. Kemal Atatürk, Nutuk, I, 1919-1920, s. 12.

${ }^{45}$ Atatürk'ün Söylev ve Demeçleri, 1919-1938, I, s. 8-9.
} 
bilhassa Ermeniler'in vahşet ve zulümlerine sahne olmuş mâtemzede hudut vilâyetlerimiz namus ve istiklâl-i milliyi kurtarmak maksadıyla Müdafaa-i Hukuk-u Milliye, Muhafaza-i Hukuk-u Milliye Cemiyetleri teşkil eylediler..."

Sivas Kongresi, Türk tarihinin bir dönüm noktası olarak değgerlendirilmelidir. Çünkü, Millî Mücadele'nin ve ülke bütünlüğünün temeli, Millî Meclis'e giden yol (23 Nisan 1920) bu kongre ile inşa ediliyordu ${ }^{46}$.

Amerikalı General James G. Harbord'un Türkiye'ye gelişi de bu döneme rastlamaktadır. Harbord başkanlığındaki bir Amerikan askerî heyeti, Amerika'nın Ermenistan üzerinde manda kurma şartlarını araştırmak üzere, Anadolu'da bir inceleme gezisine çıkmış, 20 Eylül 1919 tarihinde Sivas'a gelmiş ve Mustafa Kemal Paşa ile görüşmüştü ${ }^{47}$. Harbord heyetinin millî hareketin liderleri üzerindeki etkisi büyük olmuştur. Nitekim Harbord, Anadolu'daki millî hareketin önemini Amerikan halkına anlatmıştır ${ }^{48}$. Mustafa Kemal Paşa da, 24 Eylül 1919 tarihinde Amerika Birleşik Devletleri, İngiltere, Fransa, İtalya Yüksek Komiserleri ile Hollanda, İspanya, İsveç ve Danimarka elçiliklerine çektirdiği telgraflarda da, ülke içindeki Müslüman olmayan vatandaşların her türlü korunmasının güven altında bulunduğunu ifade etmekte $i^{4}{ }^{49}$.

Ermeniler'in pek çok zulüm gördüğüne dair, Avrupa ülkeleri tarafından yapılan propagandalara, Harbord'un raporu ile açıklık getirilmişti. Harbord raporu, iddia edilen Türk katliâmını çürütüyor ve bağımsız bir Ermenistan kurulmasına şiddetle karşı çıkıyordu ${ }^{50}$. Böylece, dünya kamuoyu TürkErmeni ilişkilerine ve Türk Millî Mücadelesi'ne artık başka bir açıdan bakmaya başlamıştı.

Fakat bu arada, İstanbul'dan Diyarbakır'a giden Piskopos Kendifyan, Ermeni Patriği Zaven Efendi'ye Ocak 1920'de yazdı̆̆ı mektubunda, Türkler'e karşı Diyarbakır'daki Ermeni örgütlenmesinden bahsediyor,

\footnotetext{
${ }^{46}$ Sivas Kongresi'nin Türk kamuoyu üzerindeki etki ve tepkileri için bkz., Emine Kısıklı, "Sivas Kong-resi'nin Millî Mücadelede Kamuoyu Oluşturulması Açısından Önemi," AÜTITED, Sayı: 1 (Mayıs 1988), s. 29-42.

${ }^{47}$ Utkan Kocatürk, Atatürk ve Türkiye Cumhuriyeti Tarihi Kronolojisi, 1918-1938, s. 97; Aynı yazar, Doğumundan Ölümüne Kadar Kaynakçalı Atatürk Günlüğü, s. 107-108; Ayrıca bkz., Fethî Tevetoğlu, "Mustafa Kemal Paşa-General Harbord Görüşmesi Tanık ve Tercümanı: Prof. Dr. Hulûsi Y. Hüseyin (Pektaş)," AAMD, Sayı: 10 (Kasım 1987), s. 197207.

${ }^{48}$ Salâhi R. Sonyel, a.g.e., s. 162.

${ }^{49}$ Utkan Kocatürk, a.g.e., s. 109.

50) Seçil Akgün, General Harbord'un Anadolu Gezisi ve (Ermeni Meselesi'ne Dair) Raporu, (Kurtuluş Savaşı Başlangıcında), İstanbul 1981, s. 133-158; Deniz Bilgen, ABD'li Gözüyle Sivas Kongresi: Amerikan Mandası ve Gazeteci L. E. Browne'tn Faaliyetleri, İstanbul 2004, s. 29.
} 
İngiliz ve Fransız teftiş memurlarının kendilerine yaptığı yardımları bildiriyordu ${ }^{51}$.

Daha sonra, 12 Ocak 1920 tarihinde İstanbul'da toplanan son Osmanlı Mebuslar Meclisi de, Anadolu'da günden güne gelişen millî hareketin gelişmesi üzerine 28 Ocak 1920 tarihinde kabul ettiği Misak-1 Millî’nin 5. maddesini, azınlıklar konusuna ayırmıştı. Bu maddede şunlar yazılı idiّ ${ }^{\text {52 }}$ :

"İtilâf Devletleri ile düşmanları ve bazı ortakları arasında kararlaştırılmış olan antlaşma esasları dairesinde azınlıkların hakları komşu memleketlerdeki Müslüman halkın da aynı haktan istifadeleri şartı ile tarafımızdan kabul ve temin edilecektir."

Ancak az sonra, 16 Mart 1920 tarihinde İstanbul İtilâf Devletleri tarafından işgal ediliyordu. Bu işgal ile, artık padişahtan ve padişah hükümetlerinden milletin kurtuluşu için hiçbir yardım beklenemez ve onunla hiçbir hususta işbirliği yapılamazdı. Bu sebeple, millî iradeyi temsil edecek teşkilâtı ortaya çıkarmak gerekiyordu. Bu teşkilât, 23 Nisan 1920 tarihinde Ankara'da kurulan Türkiye Büyük Millet Meclisi olacaktır. Artık cephelerdeki savaşları Türkiye Büyük Millet Meclisi Hükümeti yürütecektir.

\section{Sivas Kongresi Sonrası ve Sevr Antlaşması Karşısında Türk} İradesi

İşgallere karşı kurtuluş çareleri arayan Türk Milleti'nin silâhlanması,

Sivas Kongresi ile ortaya çıkan Heyet-i Temsiliye'nin dikkatini çekmiști. Bu durum, 16-29 Kasım 1919 günleri arasında Sivas'da yapılan Komutanlar Toplantısı'nda etraflıca görüşülmüş, hazırlanan plân ilgili komutanlara ve Müdafaa-i Hukuk Teşkilâtı'na bildirilmişti ${ }^{53}$. Bu cümleden olarak, 1920 yılı başlarında ve ortalarında, Mustafa Kemal Paşa'nın ve ordunun desteği ile cephelerdeki millî direniş büyük güç kazanmıştı. Artık işgal altında tutulan yerlerin kurtarılması mücadelesi başlamıştı.

Güney cephesindeki Ermeni faaliyetleri ile ilgili olarak Mustafa Kemal Paşa Bursa'ya çektiği Şifre-Tel'de, Müslüman halka karşı yapılan zulüm ve faciaları sıralıyordu". Merkezi Sivas'da bulunan "Anadolu Kadınları Müdafaa-i Vatan Cemiyeti” de, işgallere ve mezâlime karşı tutumunu Heyet-i Temsiliye ve Mustafa Kemal Paşa ile yaptığı yazışmalarında vatanperverane bir şekilde ortaya koyuyordu ${ }^{55}$. Diğer taraftan, İstanbul'daki Robert Kolej Müdürü C. F. Bates'in de, Türkiye'de bölgesel araştırma

\footnotetext{
${ }^{51}$ Osmanlı Belgelerinde Ermeniler (1915-1920), Ankara 1994, s. 260-261.

${ }^{52}$ Enver Ziya Karal, a.g.e., s. 54.

${ }^{53}$ Zeki Sarıhan, Kurtuluş Savaşı Günlüğü, II, Ankara 1984, s. 222.

54 "Haziran 1920: Cepheler-Ermeni Faaliyetleri-Millî Harekete Karşı Yeni Düzenlemeler," BTTD, Sayı: 31 (Eylül 1987), s. 8.

${ }^{55}$ Bekir Sıtkı Baykal. Millî Mücadele'de Anadolu Kadınları Müdafaa-i Vatan Cemiyeti, Ankara 1986.
} 
yapmaya gelen Amerikan Tetkik Komisyonu üyelerinden A. Lybyer'e gönderdiği 12 Nisan 1920 tarihli yazıda, Fransız yönetiminin, bölgeye Ermeni savaşçıları getirerek, onları orada jandarma ve polis olarak kullanmasının bütün Anadolu'da kötü etki yarattığını belirtiyordu ${ }^{56}$.

Doğu cephesinde de, 1920 yılının Mayıs'ında Ermeni baskısı gittikçe yoğunlaşmıştı. Bunun üzerine Mustafa Kemal Paşa, 9 Haziran 1920 tarihinde Kâzım Karabekir Paşa'yı Doğu cephesi komutanlığına atayarak Ermeni ordusunun yok edilmesi yetkisini veriyordu ${ }^{57}$.

Bu sirada müttefikler, Osmanlı İmparatorluğu'na bir an önce imzalatmak için üzerinde çalıştıkları barış antlaşması metnini ortaya koymuşlardı. Nihayet, İngiltere'nin gayretleri ile Sevr Antlaşması 10 A ğustos 1920 tarihinde Osmanlı Hükümeti'ne imzalatıldı. Antlaşmanın imzalandığı haberi Türkiye'nin her tarafında infial yaratmış ve öfke ile karșılanmıșt. ${ }^{58}$. Türkiye'yi Orta Anadolu'da birkaç vilâyete inhisar ettiren ve bağımsız devlet unsurlarını ortadan kaldıran bu antlaşma; Türkiye Büyük Millet Meclisi'nin kurulmasından önce başlamış olan Türkler'in mücadele azim ve kararını daha da artırmıştı. Bernard Lewis, antlaşmayı şöyle değerlendirmektedir ${ }^{59}$ :

"Sèvres andlaşması pek insafsızdı ve Türkiye'yi, en zengin illerini ilhak eden devletlerin ve ulusların insafına dayanarak yaşayabilecek, çaresiz, kötürüm ve gölge bir devlet halinde brrakacaktı...Türkiye'de bir ulusal yas günüyle karşılandı.

Fakat hiçbir zaman uygulanmadı. İtilâf devletleri Sultanın uysal hükümetine şartlarını dikte ederken, Anadolu'da, andlaşmayı ve ona temel olan ilkeleri tamamen reddeden ve onu kabul eden Türkleri hain olarak mahkûm eden adamların önderlik ettiği, yeni bir Türk devleti doğuyordu.

Sèvres andlaşmasının imzalanması, Türkiye'de onu kabul eden rejime karşı büyük bir duygu değiş̧ikliğine sebep oldu; eski müttefikler arasında gittikçe artan anlaşmazlıklar, Mustafa Kemal'e ayrı ayrı akıllıca görüşmelerle durumunu kuvvetlendirme imkânını verdi.,"

Sevr Antlașması'nın 88., 89. ve 93. maddeleri, Büyük Ermenistan'ın temellerini atıyordu. Bu maddelerde özetle şöyle deniliyordu ${ }^{60}$ :

\footnotetext{
${ }^{56}$ Salâhi R. Sonyel, "Tehcir ve Kırımlar Konusunda Ermeni Propagandası, Hıristiyanlık Dünyasını Nasıl Aldatt," Belleten, Sayı: 161 (Ocak 1977), s. 149.

${ }^{57}$ Selâhattin Tansel, a.g.e., III, s. 225.

${ }^{58}$ Sevr Antlaşması'nın tepkileri konusunda geniş bilgi için bkz., İzzet Öztoprak, Kurtuluş Savașinda Türk Bastmı, Ankara 1981, s. 201-242.

${ }^{59}$ Bernard Lewis, Modern Türkiye'nin Doğuşu, Ankara 1970, s. 247, 252.

${ }^{(2)}$ Nihat Erim, a.g.e., s. 559-560
} 
Madde 88 - Türkiye, Ermenistan'ı bağımsız bir devlet olarak tanır,

Madde 89 - Erzurum, Trabzon, Van ve Bitlis vilâyetlerindeki Türkiye Ermenistan sınırının tesbiti, Birleşik Amerika Başkanı'na bırakılmaktadır. Bu konudaki kararını ve Ermenistan'ın denize çıkışı ile Türk topraklarının askersizleştirilmesi hakkında öngöreceği önlemleri taraflar kabul edeceklerdir,

Madde 93 - Ermenistan, bu topraklardan geçiş serbestliğini ve ticaret eşitliğini kabul eder.

Sevr Antlaşması, Doğu'da bir Ermenistan kurduğu gibi, Kürdistan'a da otonomi vermekte ve böylece Doğu Anadolu'yu parçalamakta idi. Batılılar'ın teşvik ve yardımlarından başka Sovyetler'den de destek gören Ermeniler, antlaşmanın tanıdığı haklara dayanarak, 24 Eylül 1920 tarihinde Türk topraklarına saldırmaya başlamışlardı ${ }^{61}$. Bu durum üzerine, Kâzım Karabekir Paşa, 1 Kasım 1920 tarihinde Ermeniler'e hitaben yayınladı̆̆ beyannâmede, Taşnaklar'ın Ermeni toplumuna yaptığı kötülükleri sıralayarak şunları söylüyordu" ${ }^{62}$ : "Maksadımız ve hedefimiz...Müslüman ve Ermeni fukara halkını kırdıran Taşnaklar'ın elinden masum halkı kurtarmaktır.".

Bu arada Türk askerî hareketi de Gümrü istikametinde hızla gelişmiş ve 6 Kasım 1920 tarihinde, Türk kuvvetleri, Gümrü çevresindeki istihkâmlar önüne gelmişti. Bu durumda Ermeniler, aynı gün akşamı, mütareke istediler. Gümrü'de devam eden müzakereler, 2/3 Aralık 1920 tarihinde imzalanan Gümrü (Alexandropol) Antlaşması ile sonuçland ${ }^{63}$. Türkiye Büyük Millet Meclisi'nin ilk askerî başarısı sonucu ilk antlașma olan Gümrü Antlașması ile Kars, Sarıkamıs, Kağ katıldı. Ancak, 5 Aralık 1920 tarihinde Ermenistan Sovyetleștirilmişti ${ }^{64}$. Bu sebeple, Gümrü Antlaşması'na rağmen, Ermenistan meselesi halledilmiş sayılmazdı. Artık mesele, Türkiye ile Rusya arasında devam edecek ve nihayet TBMM Hükümeti ile SSCB Hükümeti arasında 16 Mart 1921 tarihinde imzalanan Moskova Antlaşması ve yine 13 Ekim 1921 tarihinde imzalanan Kars Antlaşması ile halledilecektir ${ }^{65}$.

Böylece Sevr Antlaşması'nın Doğu'da yaratmak istediği Büyük Ermenistan düşüncesi, Mustafa Kemal Paşa ordularının ayakları altında çiğnenmiş oluyordu. Doğu'da kazanılan bu başarı, milliyetçilerin morallerinin daha da yükselmesine yardım etmiştir.

\footnotetext{
${ }^{61}$ Utkan Kocatürk, Atatürk ve Türkiye Cumhuriyeti Tarihi Kronolojisi, 1918-1938, s. 203.

${ }^{6.2}$ Kâzım Karabekir. a.g.e.. s. 842.

${ }^{63}$ Kâzım Karabekir, a.g.e., s. 841-846.

${ }^{64}$ Gotthard Jaeschke. Türk Kurtuluş Savaşı Kronolojisi, I, s. 131.

*5 İsmail Soysal, Tarihçeleri ve Açıklamalart lle Birlikte Türkive'nin Siyasal Andlașmalart, 1920-1945, I. Cilt, Ankara 1983, s. 27-38. 39-47.
} 
Güney cephesinde de, yıldırıcı ve yıpratıcı bir gerilla savaşının başlaması üzerine Fransızlar da, Türk topraklarında tutunamayacaklarını anlamışlardı. Fransızlar'ın Suriye Olağanüstü Komiseri Ankara'ya başvurarak 20 günlük bir mütareke istedi. Bu durum, Fransızlar'in Büyük Millet Meclisi Hükümeti'ni zımnen tanımaları demekti. Bu durumda, Fransızlar'ın bölgeyi boşaltacağını duyan Ermeniler artık kitleler halinde göç etmeye başlamışlardı. Fransızlar bir süre askerî hareketlerini durdurduktan sonra, Sakarya Zaferi üzerine 20 Ekim 1921 tarihinde TBMM Hükümeti ile Ankara Antlaşması'nı imzalayarak ${ }^{66}$, Hatay dışında işgal ettikleri yerleri geri veriyorlardı. Böylece, Millî Mücadele'nin Güney cephesi de kapanmış oluyordu. Ankara Antlaşması, yalnız bu bakımdan değil, Türkiye'nin Batı karşısındaki genel durumu bakımından da çok önemli idi. Fiilî değeri olmadığı çoktan anlaşılan Sevr Antlaşması böylece, hukuken de hükümsüz kaliyordu $^{67}$.

Ermeni istekleri, millî teşekküllerin sebatkârane tutumları karşısında 11 Ekim 1922 tarihinde imzalanan Mudanya Mütârekesi ile sonuçsuz kalıyordu. Artık İtilâf Devletleri, "Büyük Ermenistan” davasından ümitlerini kesmişler, fakat eski müttefiklerini Güney ve Güneydoğu Anadolu’da kurulacak olan "Ocak" veya "Ermeni Yurdu" gibi boş sözler ile avutmak ve Ermeni hâmiliğinden sıyrılmanın çarelerini aramaya başlamışlardı. Lozan'da da bu yolda gayret göstermişler, ancak netice alamamışlardı ${ }^{68}$. Böylece, sözde "Ermeni Meselesi”, Lozan'da tarihin derinliklerine gömülmüştü.

\section{SONUÇ}

Mondros Mütarekesi, Osmanlı İmparatorluğu'nun fiilen sonunu getirmiş, Sevr Antlaşması da bu sonucu, İtilâf Devletleri'nin tek yönlü yargıları ile bütünleştirmişti. Ancak, Yunanlılar'ı ve Ermeniler'i Anadolu macerasına itenler, Türk'ün, Mustafa Kemal Paşa önderliğinde birleşeceğini düşünememişlerdi.

1919-1922 yılları arasında millî uyanışın ve direnişin sebebi, anavatan topraklarında bir Yunan ve Ermeni devleti kurulmak istenmesi idi. Halbuki toplantılarda ve konferanslarda Ermeni edebiyatı yapan İtilâf Devletleri temsilcileri Sevr'de çizilen Ermenistan sınırlarını gerçekleştirebilecek durumda değillerdi. Çünkü onlar, ne bir kuruş verecek ve ne de bir tek asker gönderebilecek durumda idiler. Meselâ, Ermenistan mandaterliğine itilmeye çalışılan Amerika Birleşik Devletleri bile bu sorumluluğu yüklenmeyi kabul etmemişti.

İtilâf Devletleri, millî uyanış bayrağı karşısında nihayet Lozan'da, Türkiye Cumhuriyeti Devleti toprakları üzerinde bir Ermenistan yaratılamayacağını kabul etmek zorunda kalmışlardı.

${ }^{66}$ İsmail Soysal, a.g.e., s. 48-60.

${ }^{67}$ Ankara Antlașması'nın önemi ve yankıları için bkz., Yahya Akyüz, a.g.e., s. 147-151.

${ }^{68}$ Esat Uras, a.g.e., s. 723-756. 


\section{KAYNAKLAR}

\section{KITAPLAR}

Adalian, Rouben Paul, Historical Dictionary of Armenia, Lanham, Maryland and Oxford 2002.

Akgün, Seçil, General Harbord'un Anadolu Gezisi ve (Ermeni Meselesi'ne Dair) Raporu, (Kurtuluş Savaşı Başlangıcında), İstanbul 1981.

Akyüz, Yahya, Türk Kurtuluş Savaşı ve Fransız Kamuoyu (1919-1922), Ankara 1975.

Atatürk, M. Kemal, Nutuk, I, 1919-1920, İstanbul 1967.

Atatürk'ün Söylev ve Demeçleri, 1919-1938, I, 3. Bask1, Toplayan: Nimet Arsan, Ankara 1981.

Baykal, Bekir Sitkı (yay.haz.), Erzurum Kongresi Ile İlgili Belgeler, Ankara 1969.

Ankara 1986

Millî Mücadele'de Anadolu Kadınlarl Müdafaa-i Vatan Cemiyeti,

Bıyıklığlu, Tevfik, Atatürk Anadolu'da (1919-1921), I, Ankara 1959.

, Trakya'da Millî Mücadele, I. Cilt, 2. Baskı, Ankara 1987.

Bilgen, Deniz, ABD'li Gözüyle Sivas Kongresi: Amerikan Mandası ve Gazeteci L. E. Browne'ın Faaliyetleri, İstanbul 2004.

Devlet Arşivleri Genel Müdürlüğü, Osmanlı Belgelerinde Ermeniler (1915-1920), Ankara 1994.

Dursunoğlu, Cevat, Millî Mücadele'de Erzurum, Ankara 1946.

Erim, Nihat, Devletlerarast Hukuku ve Siyasî Tarih Metinleri: Osmanlt İmparatorluğu Andlaşmaları, Cilt I, Ankara 1953.

Erol, Mine, Türkiye'de Amerikan Mandast Meselesi (1919-1920), Giresun 1972.

Gökbilgin, M. Tayyib, Millî Mücadele Başlarken: Mondros Mütarekesinden Sivas Kongresine, I, Ankara 1959.

Jaeschke, Gotthard, Türk Kurtuluş Savaşı Kronolojisi, I, Ankara 1970.

, Kurtuluş Savaşı İle Illgili İngiliz Belgeleri, Ankara 1971.

Karabekir, Kâzım, İstiklâl Harbimiz, İstanbul 1969.

Karal, Enver Ziya, Tïrkiye Cumhuriyeti Tarihi, 1918-1965, İstanbul 1971.

Kırzıoğlu, M. Fahrettin, Kars Tarihi, I, İstanbul 1953.

, Millî Mücadelede Kars, I. Kitap, İstanbul 1960.

, Kars İli ve Çevresinde Ermeni Mezâlimi (1918-1920), Ankara 1970.

Kocatürk, Utkan, Atatürk ve Türkiye Cumhuriyeti Tarihi Kronolojisi, 1918-1938, Ankara 1983. 
1988.

, Doğumundan Ölïmüne Kadar Kaynakçalı Atatürk Günlïğ̈̈, Ankara

Lewis, Bernard, Modern Türkiye'nin Doğuşu, Ankara 1970.

Öke, M. Kemal, Ingiltere'nin Gïneydoğu Anadolu Siyaseti ve Binbașı E. W. C. Noel'in Faaliyetleri, Ankara 1988.

Öztoprak, İzzet, Kurtuluş Savaşında Türk Basını, Ankara 1981.

Pasdermadjian, H., Histoire de L'Arménie, Paris 1949-1971.

Sarıhan, Zeki, Kurtuluş Savaşı Günlüğü, I-III, Ankara 1984-1993.

Selek, Sabahattin, Anadolu Ihtilâli, 4. Baskı, İstanbul 1968.

Shaw, Stanford J., and Shaw, Ezel Kural, History of the Ottoman Empire and Modern Turkey, II, Reprinted 1978.

Sonyel, Salâhi R., Türk Kurtuluş Savașı ve Dış Politika, I, Ankara 1973.

Soysal, İsmail, Tarihçeleri ve Açıklamaları İle Birlikte Türkiye'nin Siyasal Andlaşmaları, 1920-1945, I. Cilt, Ankara 1983.

Tansel, Selâhattin, Mondros'tan Mudanya'ya Kadar, I-III, Ankara 1973.

Tevetoğlu, Fethî, Millî Mïcâdele Yıllarındaki Kuruluşlar, Ankara 1988.

Tunaya, Tarık Zafer, Türkiye'de Siyasal Partiler, II. Cilt, 2. Baskı, İstanbul 1986.

Uras, Esat, Tarihte Ermeniler ve Ermeni Meselesi, Ankara 1950.

Walker, Christopher J., Armenia: The Survival of a Nation, London 1980.

\section{MAKALELER}

Baykal, Bekir Sıtkı, "İzmir'in Yunanlılar Tarafından İşgali ve Bu Olayın Doğu Anadolu'daki Tepkileri," Belleten, Sayı: 132, Ankara 1969, s. 517-535.

"Haziran 1920: Cepheler-Ermeni Faaliyetleri-Millî Harekete Karşı Yeni Düzenlemeler," BTTD, Sayı: 31 (Eylül 1987), s. 4-10.

İlter, Erdal, "Ardahan'ın Düșman İşgalinden Kurtuluşunun 52. Y1l Dönümü,” Türk Kültürü, Say1: 123 (Ocak 1973), s. 129-137.

Kırzıoğlu, M. Fahrettin, "Cihângîroğlu İbrâhim Aydın (1874-1948)'daki MillîMücadele'de Kars ve Atatürk ile İlgili Belgeler," Belleten, Sayı: 189-190 (OcakNisan 1984), s. 109-165.

Kısıklı, Emine, "Sivas Kongresi’nin Millî Mücadelede Kamuoyu Olușturulması Açısından Önemi," AÜTiTED, Sayı: 1 (Mayıs 1988), s. 29-42.

Öztoprak, İzzet, "Trabzon Muhafaza-i Hukuk-u Milliye Cemiyeti," Birinci Tarih Boyunca Karadeniz Kongresi Bildirileri, Samsun 1988, s. 335-350.

Özkaya, Yücel, "İzmir'in İşgalinin Anadolu'daki Tepkileri,” AÜTITED, Sayı: 1 (Mayıs 1988), s. 65-74. 
Sonyel, Salâhi R., "Tehcir ve Kırımlar Konusunda Ermeni Propagandası, Hıristiyanlık Dünyasını Nasıl Aldattı," Belleten, Sayı: 161 (Ocak 1977), s. 137156.

Tevetoğlu, Fethî, "Mustafa Kemal Paşa-General Harbord Görüşmesi Tanık ve Tercümanı: Prof. Dr. Hulûsi Y. Hüseyin (Pektaş)," AAMD, Sayı: 10 (Kasım 1987), s. 197-207. 